\title{
EXCHANGE OF MATERIALS IN A LAKE AS STUDIED BY RADIOACTIVE PHOSPHORUS
}

\author{
By Prof. C. C. GOFFIN, Dr. F. R. HAYES, L. H. JODREY and S. G. WHITEWAY \\ Departments of Chemistry and Zoology, Dalhousie University, and \\ Fisheries Division, Nova Scotia Department of Trade and Industry
}

\section{$\mathrm{S}$} HORTLY after dawn on July 1, 1948, the $S$ weather being fine and calm, 100 millicuries of radioactive phosphorus $\left(\mathrm{P}^{32}\right)$ was added to the surface of an acid bog laly of area 0.3 hectare $(0.8$ acre) and depth 6 metres, situated near Halifax, Nova Scotia. The ryn-off was small and the margin almost wholly surrounded by sphagnum. The lake had a well-developed zone of cold, stagnant water at the bottom with a thermocline above. Oxygen reached two-thrds saturation at the surface, was scarce at three metres depth, and absent at five metres. The only native fish observed were Fundulus diaphanus and Notemigonus crysoleucas. Before the experiment, some four thousand Fundulus were added to the lake for later sampling.

The added phosphorus-32, being mixed by means of an outboard motor, was initially distributed evenly to a depth of some 1.5 metres. Within two hours there was a specific removal of phosphorus-32 from the surface water, so that the maximum concentration was one metre down. This is believed to be related to the overhanging margins of floating sphagnum. The peak had disappeared 13 hours after zero time. Penetration of added phosphorus into the lake depths was very slow, and even at the end of eight weeks the material was only doubtfully detected at the bottom. There was no evidence of active uptake by bottom mud.

The total phosphorus-32 in the lake declined for 8 hours, rose again at 13 hours, and afterwards declined steadily. The uptake by sphagnum showed a reciprocal relation, with a peak at 8 hours and a trough at 13. Assuming that the increase in lake phosphorus is due to liberation by sphagnum, it is possible to calculate the quantity of actively growing, or at least participating, sphagnum, which works out at 1.5 metric tons.

Although no great confidence is to be placed in this value until checked, the method opens interesting possibilities in aquatic studies. The uptake by sphagnum exhibited a second peak at about three weeks. It appears reasonable to think that sphagnum possesses two mechanisms of phosphorus uptake, the first of which might be due to physical processes unconnected with active cell metabolism. The second peak might be due to the incorporation of phosphorus into the protoplasm in some permanent way.

Samples of plankton, collected from time to time, turned out to be practically pure cultures of Diaptomus. Uptake of phosphorus-32 was apparent within five hours and reached a peak in eight days.

The situation as regards plankton is quite different from that of sphagnum, the former being composed of animals whose lives are of short duration, so that the counts of phosphorus-32 do not represent the conditions in a single generation which lives through the summer, but in several generations.

No phosphorus-32 could be found in fish until some fifty hours after the beginning of the experiment. Such a late beginning of deposition contrasts with the early uptake by plankton, and suggests that different mechanisms may be operating. In the case of the plankton, it is easy to imagine that inorganic phosphate is taken up directly, while in the fish the timelag suggests that the phosphorus-32 must first be taken up by the plankton organisms and incorporated into their tissues. The fish would then receive phosphorus by eating the plankton.

No phosphorus-32 was detected in the leaves of marginal rooted organisms until a fortnight after the experiment began. The delayed appearance suggests that phosphorus reached the leaves via the roots.

Four counts on the alga Batrachospermum were also made between nine days and eight weeks from zero time. No trend was discernible, the maximum value being already established by the time the first count was made. It is reasonable to think that such a form would take up phosphorus quickly; but proof is not at hand.

The intensity of phosphorus assimilation can be calculated in two ways. First, we may give the absolute uptake, which is the ratio of the maximum observed value for an organism compared to the maximum value for the same weight of water. The relationship can be derived from Fig. 1, in which it is seen that animals take up more than plants; higher animals more than lower animals; and lower plants more than higher plants. As regards the last statement, however, it must be remembered that the measurements on whole algæ and on all exposed parts of sphagnum are not strictly comparable to the leaf counts made on higher plants. It was observed that the growing tips of a higher plant gave greater counts than leaves.

A second calculation gives the relative uptake by answering the question: How much phosphorus-32 can be taken up in proportion to the total phosphorus already in the organism ? This is a measure of the rate of turnover of phosphorus.

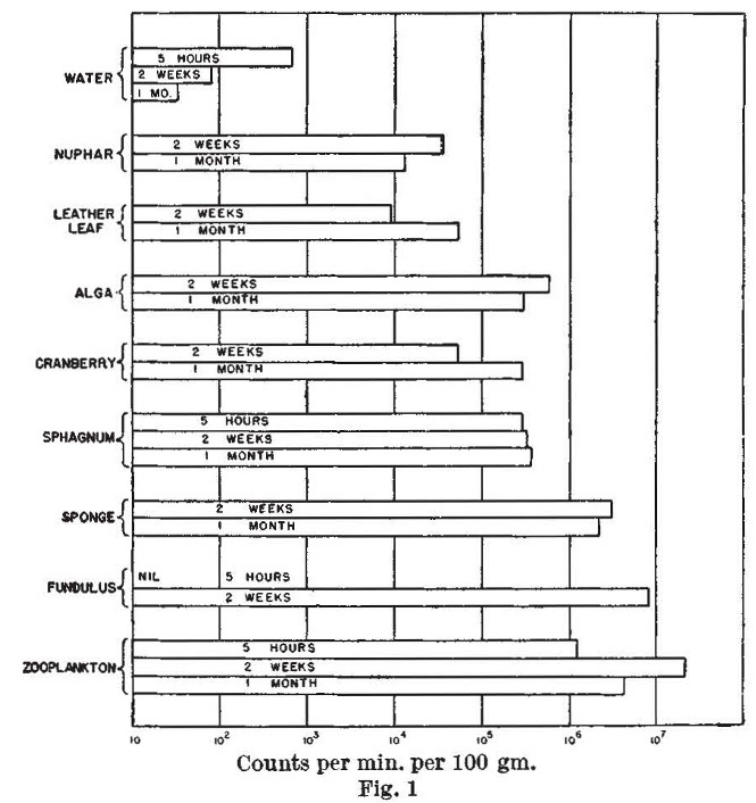


Ratio of phosphorus-32 to total phosphorus in organism $\times 10^{-7}$

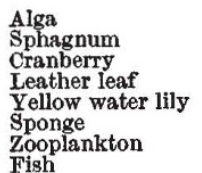

As the table shows, maximal values are observed for alga and sponge, the simplest forms dealt with. Next, but much lower, come sphagnum and Diap. tomus. Fish and higher plants make up a still more sluggish group. The high value for Diaptomus as compared with fish is, perhaps, related to $(a)$ the short life of a generation of plankton organisms, making a rapid turnover of material necessary, and $(b)$ the mass of inorganic phosphate in a fish skeleton, which is renewed fairly slowly. This slow exchange is demonstrable by radioautographs. No specific deposition was observed at nine days, but by fifteen days Notemigonus, as shown in Fig. 2, had laid down the phosphorus-32 in the axial skeleton and at the bases of the fins.

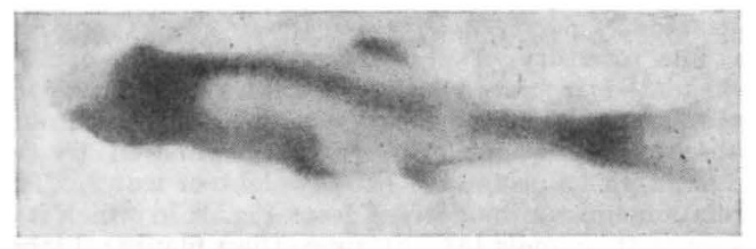

Fig. 2

In both systems of measuring intensity of uptake, the sphagnum ratios are below some of the others. Nevertheless, sphagnum is believed to be the main agent for the removal of phosphorus-32 in this lake, because of its great abundance.

A full account of this work will be published elsewhere.

\section{D.D.T.-RESISTANCE IN HOUSE- FLIES IN DENMARK} By J. KEPING and H. VAN DEURS Statens Skadedyrlaboratorium, Springforbi, Denmark

CINCE garly in 1944, when insecticidal products $S$ contgining D.D.T. were first put on the market in Dentnark, a great proportion of the available D.D.T. has been used for fly control on our farms. The/commonest practice has been to spray the inside of cowsheds, pigsties, etc., with a water suspension of emulsion, usually containing not more than $0.05-0.1$ per cent D.D.T., at the rate of about 0.1-0.2 gm. D.D.T. per sq. metre. The spraying must be carefully done. This dosage may seem rather small; but in the first year or two it worked well in most places, and many farmers were able to keep their farm buildings free from flies by spraying two or three times a year.

In 1944 only a comparatively small percentage of the farmers in Denmark used D.D.T. against flies. In 1945 many dairies started control of flies by regular spraying of the cowsheds, etc., of their suppliers, and in 1946 this organised control was in action all over the country.

Already in 1946 there were some isolated com. plaints of failing effect, and in the summer of 1947 the fly control failed in a great many places. It was attributed to careless spraying, as well as to the unusually hot summer, the effect of the high temperature being an increased production of flies in the dung-heaps, etc., a decrease in the toxicity of D.D.T. to insects ${ }^{1}$, and possibly a more rapid deterioration of the deposits on limewashed surfaces ${ }^{2}$.

Early in 1948 we received accounts from various places of flies which "could not be killed with D.D.T.", even with much higher dosages than usually recom. mended. Houseflies (adults, pupæ and larvæ) were collected from six of these places and the strains so obtained $\left(r_{1}, r_{2}, r_{3}\right.$, etc.) were bred by a modified N.A.I.D.M. procedure ${ }^{3}$ in parallel with the non. resistant laboratory strain (lab) which has been bred from flies taken on a farm near Copenhagen in October 1945.

The results of the first laboratory tests showed unmistakably that all six $r$-strains were several times more resistant to D.D.T. than the laboratory strain.

In order to simulate our common type of stable wall, lime-washed flowerpots (6 in. in diameter) were used as test containers and sprayed (or dusted) evenly on the inside with measured dosages of insecticide. Most of the tests were made by exposing the flies continuously to the treated surface, the opening of a container being covered with a loose glass plate during tests.

The first results were confirmed in a great number of laboratory tests with several D.D.T. residualspray formulations, dusts, etc., using later generations of the $r$ - and lab-strains. Whereas the lab-flies might be 'knocked down' and moribund within an hour or even half an hour with a dose of $2 \mathrm{gm}$. D.D.T. per square metre, some of the $r$-flies could live for days exposed to the same surface; we have even had $r$-flies, white all over with 33 per cent D.D.T.-dust, which lived for several days. In the accompanying table, examples are given of some of the initial tests with three of the $r$-strains and the lab-flies.

Reaction of lab-flies and $r$-flies to continuous exposure to residualspray deposits of D.D.T. on limewash

\begin{tabular}{|c|c|c|c|c|c|c|c|c|}
\hline \multirow{2}{*}{ 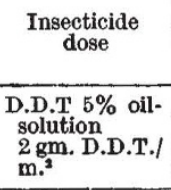 } & \multicolumn{2}{|c|}{ Strain $\stackrel{\text { Flies }}{\text { Number }}$} & \multicolumn{6}{|c|}{ 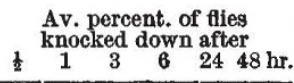 } \\
\hline & $\begin{array}{l}\text { lab } \\
r_{1} \\
r_{2} \\
r_{3}\end{array}$ & $\begin{array}{l}29+26+31 \\
19 \\
25+18 \\
22+11\end{array}$ & $\begin{array}{r}94 \\
0 \\
0 \\
0\end{array}$ & $\begin{array}{r}100 \\
0 \\
2 \\
0\end{array}$ & $\begin{array}{r}0 \\
37 \\
3\end{array}$ & $\begin{array}{r}0 \\
40 \\
6\end{array}$ & $\begin{array}{l}11 \\
58 \\
18\end{array}$ & $\begin{array}{l}11 \\
72 \\
36\end{array}$ \\
\hline $\begin{array}{l}\text { D.D.T. } 25 \% \\
\text { wettable } \\
\text { powder } \\
2 \text { gm. D.D.T./ } \\
\text { m.2 }\end{array}$ & $\begin{array}{l}\text { lab } \\
r_{1} \\
r_{2} \\
r_{s}\end{array}$ & $\begin{array}{l}22+29+34 \\
22 \\
40+20 \\
22+7\end{array}$ & $\begin{array}{r}87 \\
0 \\
2 \\
0\end{array}$ & $\begin{array}{r}100 \\
0 \\
17 \\
7\end{array}$ & $\begin{array}{r}0 \\
38 \\
21\end{array}$ & $\begin{array}{r}0 \\
47 \\
24\end{array}$ & $\begin{array}{l}68 \\
98 \\
66\end{array}$ & $\begin{array}{l}68 \\
98 \\
76\end{array}$ \\
\hline $\begin{array}{l}\text { D.D.T. } 25 \% \\
\text { wettable } \\
\text { powder } \\
1 \text { gm.D.D.T./ } \\
\text { m. }\end{array}$ & $\begin{array}{l}\text { lab } \\
r_{1} \\
r_{2} \\
r_{3}\end{array}$ & $\begin{array}{l}25+31+32 \\
21 \\
42+30 \\
20+7\end{array}$ & $\begin{array}{r}90 \\
0 \\
0 \\
0\end{array}$ & $\begin{array}{r}100 \\
0 \\
6 \\
0\end{array}$ & $\begin{array}{r}0 \\
28 \\
7\end{array}$ & $\begin{array}{r}10 \\
40 \\
7\end{array}$ & $\begin{array}{r}43 \\
100 \\
52\end{array}$ & $\begin{array}{l}52 \\
70\end{array}$ \\
\hline
\end{tabular}

The resistance was not quite the same in all the $r$-strains, as one might expect ; in later generations, however, the differences have become slight, as the resistance of the most resistant strains has decreased although it is still remarkably high after seven tc nine generations. In order to secure a highly resistant strain, some flies were bred in a cage treated with a whitewash containing about 0.3 per cent D.D.T.

Since the demonstration of D.D.T.-resistance in the laboratory, we have had numerous reports of 